\title{
Prunusols A and B, Novel Antioxidative Tocopherol Derivatives Isolated from the Leaf Wax of Prunus grayana Maxim.
}

\author{
Toshihiko Osawa, Shigenori Kumazawa and Shunro KawaKishi \\ Department of Food Science and Technology, Nagoya University, \\ Chikusa, Nagoya 464-01, Japan
}

Received November 19, 1990

\begin{abstract}
Novel antioxidative phenylpropanoid-substituted tocopherol derivatives, prunusols $A$ and B, were isolated from the leaf wax of Prunus grayana Maxim., and their structures were fully characterized by spectroscopic and synthetic methods. Prunusols $A$ and $B$ were found to be the conjugates of $\gamma$-tocopherol and p-coumaric acid, which are diastereoisomers of each other. They showed almost the same antioxidative activity as $\alpha$-tocopherol in a water/alcohol system measured by thiocyanate and TBA methods.
\end{abstract}

Recently, much attention has been focused on the antioxidative defence mechanisms in living cells against damage caused by active oxygen and free radicals. ${ }^{1,2)}$ In plants, endogenous natural antioxidants have been speculated to play an important role in non-enzymatic protections in addition to enzymatic inactivation by antioxidative enzymes such as superoxide dismutase, catalase and glutathione-peroxidase. Many different types of natural antioxidants have already been found in numerous plants, although the chemical properties and physiological roles of active components are not fully understood. ${ }^{3)}$

The authors have been involved in isolating and identifying natural antioxidants from plant materials, ${ }^{4}$ in particular, from plant leaf wax, and the $\beta$-diketone type of antioxidant was isolated and identified in leaf wax extracted from Eucalyptus globulus. ${ }^{5,6)}$ Recently, we have screened various species of plant leaf waxes for an evaluation of antioxidative activity, ${ }^{7}$ and the leaf wax of Prunus grayana Maxim. was suggested to contain antioxidative compounds that were different from tocopherols. In this paper, we report the structural elucidation of novel antioxidative tocopherol derivatives named prunusols $\mathrm{A}$ and $\mathrm{B}$, which may play an important role in the antioxidative defence systems of plant leaf wax.

\section{Materials and Methods}

Instruments for structural determination. Spectroscopic measurements were carried out by using the following

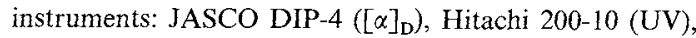
JASCO A-3 (IR), JEOL DX-705L (MS), JEOL FX 200 (NMR), JEOL GX 500 (NMR) and JASCO J-40A (CD).

Extraction of the leaf wax. Prunus grayana Maxim. leaves $(35 \mathrm{~kg})$ that had been collected in Takayama City, Gifu, Japan, in July 1986, were extracted twice with 1501 of chloroform. The chloroform extract was filtered and concentrated in vacuo to give $400 \mathrm{~g}$ of leaf wax. A part of the leaf wax (c. $140 \mathrm{~g}$ ) was charged in a silica gel column (Fuji-Davison BW-300, $100 \phi \times 600 \mathrm{~mm}$ ) and eluted with hexane-ethyl acetate by a stepwise increase in the volume of ethyl acetate. Five fractions eluted with hexane-ethyl acetate $(9: 1,8: 2,6: 4,5: 5$ and $4: 6, \mathrm{v} / \mathrm{v})$ showed antioxidative activity in a water/alcohol system measured by the thiocyanate method. ${ }^{8)}$ The fractions eluted with $9: 1$ $(\mathrm{v} / \mathrm{v})$ and $8: 2(\mathrm{v} / \mathrm{v})$ hexane ethyl acetate were confirmed to contain $\gamma$-tocopherol: however, the fractions eluted with the other hexane-ethyl acetate ratios $(6: 4,5: 5$ and $4: 6$, $\mathrm{v} / \mathrm{v})$ were considered to contain unknown antioxidative compounds whose $R f$ values were lower than those of tocopherols by a TLC analysis. These fractions were combined $(48.9 \mathrm{~g})$, charged in a silica gel column (FujiDavison BW300, $80 \phi \times 600 \mathrm{~mm}$ ), and the fractions eluted with $8: 2$ and $7: 3, v / v$ of benzene-ethyl acetate were found to show strong antioxidative activity. The active fraction $(310 \mathrm{mg})$ was further purified by preparative TLC (Merck $60 \mathrm{~F}_{254}, 1 \mathrm{~mm}$ thickness) with $\mathrm{CHCl}_{3}-\mathrm{MeOH}$ $(98: 2, \mathrm{v} / \mathrm{v})$ as the solvent system, and repurified by preparative HPLC (Develosil SI $60,20 \phi \times 250 \mathrm{~mm}$ ) with hexane-ethyl acetate $(85: 15, v / v)$ as the solvent system. 
The active compounds (prunusols $A$ and $B$ ) were obtained as oily substances, the yield of prunusol A (1) being $20.9 \mathrm{mg}$ and prunusol $\mathrm{B}(2)$ being $15.1 \mathrm{mg}$.

Prunusol $A(1) .[\alpha]_{\mathrm{D}}^{25}+15\left(c=0.2, \mathrm{CHCl}_{3}\right) ; \mathrm{UV} \hat{\lambda}_{\text {max }}$ (EtOH): $285 \mathrm{~nm}(\varepsilon=5900)$; IR $v_{\max }\left(\mathrm{CHCl}_{3}\right) \mathrm{cm}^{-1}: 3600$, $3300,2900,1750,1620,1510,1460,1380,1340,1200,1140$,

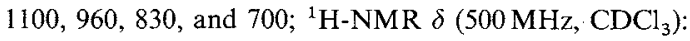
$1.20\left(3 \mathrm{H}, \mathrm{s}, 2-\mathrm{CH}_{3}\right), 1.62(1 \mathrm{H}, \mathrm{ddd}, J=16.3,7.5$ and $6.9 \mathrm{~Hz}$, $\mathrm{H}_{3 \alpha}$ ), 1.79 ( $1 \mathrm{H}$, ddd, $J=16.3,7.5$ and $\left.6.9 \mathrm{~Hz}, \mathrm{H}_{3 \beta}\right), 2.15$ $\left(3 \mathrm{H}, \mathrm{s}, 8-\mathrm{CH}_{3}\right), 2.25\left(3 \mathrm{H}, \mathrm{s}, 7-\mathrm{CH}_{3}\right), 2.29(\mathrm{HH}, \mathrm{ddd}, J=16.9$, 7.5 and $\left.6.9 \mathrm{~Hz}, \mathrm{H}_{4 \alpha}\right), 2.64(1 \mathrm{H}$, ddd, $J=16.9,7.5$ and $6.9 \mathrm{~Hz}$, $\left.\mathrm{H}_{4 \beta}\right), 2.94\left(1 \mathrm{H}\right.$, dd, $J=16.3$ and $\left.2.5 \mathrm{~Hz}, \mathrm{H}_{11 \alpha}\right), 2.99(1 \mathrm{H}$, $\mathrm{dd}, J=16.3$ and $\left.6.3 \mathrm{~Hz}, \mathrm{H}_{11} \beta\right), 4.25(1 \mathrm{H}, \mathrm{dd}, J=6.3$ and $\left.2.5 \mathrm{~Hz}, \mathrm{H}_{12}\right), 5.65\left(1 \mathrm{H}\right.$, br.s, $\left.4^{\prime \prime}-\mathrm{OH}\right), 6.66(2 \mathrm{H}, \mathrm{d}, J=$ $7.5 \mathrm{~Hz}, \mathrm{H}_{3^{\prime \prime}}$ and $\left.\mathrm{H}_{5^{\prime \prime}}\right)$ and $6.87\left(2 \mathrm{H}, \mathrm{d}, J=7.5 \mathrm{~Hz}, \mathrm{H}_{2^{\prime \prime}}\right.$ and

Table I. ${ }^{13}$ C-NMR DATA FOR $\gamma$-TOCOPHEROL, 1 AND $2^{a}$

\begin{tabular}{|c|c|c|c|c|c|c|}
\hline \multirow[b]{2}{*}{2} & \multicolumn{2}{|c|}{$\gamma$-Tocopherol } & \multicolumn{2}{|l|}{1} & \multicolumn{2}{|l|}{2} \\
\hline & 75.4 & $(s)^{d}$ & 75.3 & $(\mathrm{~s})^{d}$ & 75.5 & $(s)^{d}$ \\
\hline 2- $\mathrm{CH}_{3}$ & 24.2 & (q) & 24.2 & (q) & 23.3 & (q) \\
\hline 3 & 31.5 & (t) & 30.8 & (t) & 30.9 & $(t)$ \\
\hline 4 & 22.4 & (t) & 19.7 & $(\mathrm{t})$ & 19.8 & (t) \\
\hline $4 a$ & 118.2 & (s) & 119.8 & (s) & 119.8 & (s) \\
\hline 5 & 112.1 & (d) & 115.3 & (s) & 115.5 & (s) \\
\hline 6 & 146.2 & $(s)$ & 148.1 & (s) & 148.3 & (s) \\
\hline 7 & 121.6 & (s) & 123.6 & (s) & 123.8 & (s) \\
\hline 7- $\mathrm{CH}_{3}$ & 12.1 & (q) & 12.0 & (q) & 12.2 & (q) \\
\hline 8 & 125.6 & (s) & 125.4 & (s) & 125.5 & (s) \\
\hline $8 \mathrm{a}$ & 144.0 & (s) & 143.0 & (s) & 143.2 & (s) \\
\hline $8-\mathrm{CH}_{3}$ & 12.0 & (q) & 11.8 & (q) & 11.9 & (q) \\
\hline 10 & - & & 168.5 & (s) & 168.6 & (s) \\
\hline 11 & - & & 37.9 & $(t)$ & 38.0 & $(\mathrm{t})$ \\
\hline 12 & - & & 36.9 & (d) & 37.0 & (d) \\
\hline $1^{\prime}$ & 40.1 & $(t)$ & 39.3 & $(t)$ & 40.7 & $(t)$ \\
\hline $2^{\prime}$ & 21.1 & (t) & 21.0 & (t) & 20.8 & $(t)$ \\
\hline $3^{\prime}, 4^{\prime}, 7^{\prime}, 9^{\prime}$ & 37.5 & $(t)$ & 37.4 & $(t)$ & 37.4 & $(t)$ \\
\hline $4^{\prime}$ & $32.8^{b}$ & (d) & $32.7^{b}$ & (d) & $32.8^{b}$ & (d) \\
\hline $4^{\prime}-\mathrm{CH}_{3}$ & $19.8^{c}$ & (q) & $19.6^{c}$ & (q) & $19.7^{c}$ & (q) \\
\hline $6^{\prime}$ & 24.5 & (t) & 24.4 & $(t)$ & 24.5 & $(t)$ \\
\hline $8^{\prime}$ & $32.7^{b}$ & (d) & $32.6^{b}$ & (d) & $32.5^{b}$ & (d) \\
\hline $8^{\prime}-\mathrm{CH}_{3}$ & $19.7^{c}$ & (q) & $19.2^{c}$ & (q) & $19.4^{c}$ & (q) \\
\hline $10^{\prime}$ & 24.9 & (t) & 24.7 & (t) & 24.9 & $(\mathrm{t})$ \\
\hline $11^{\prime}$ & 39.4 & $(\mathrm{t})$ & 39.1 & (t) & 39.4 & $(\mathrm{t})$ \\
\hline $12^{\prime}$ & 28.0 & (d) & 27.9 & (d) & 28.0 & (d) \\
\hline $12^{\prime}-\mathrm{CH}_{3}, 13^{\prime}$ & 22.8 & (q) & 22.6 & (q) & 22.8 & (q) \\
\hline $1^{\prime \prime}$ & - & & 131.7 & $(\mathrm{~s})$ & 131.8 & (s) \\
\hline $2^{\prime \prime}$ & - & & 127.9 & (d) & 128.0 & (d) \\
\hline $3^{\prime \prime}$ & - & & 115.7 & (d) & 115.8 & (d) \\
\hline $4^{\prime \prime}$ & - & & 154.7 & (s) & 154.9 & (s) \\
\hline $5^{\prime \prime}$ & - & & 115.7 & (d) & 115.8 & (d) \\
\hline $6^{\prime \prime}$ & - & & 127.9 & (d) & 128.0 & (d) \\
\hline
\end{tabular}

a Measured at $50 \mathrm{MHz}$ in $\mathrm{CDCl}_{3}$.

$b, c$. Assignments may be interchanged.

${ }^{d}$ Multiplicity: s, singlet; d, doublet; t, triplet; q, quartet.
$\left.\mathrm{H}_{6^{\prime \prime}}\right)$; EI-MS $m / z: 562\left(\mathrm{M}^{+}\right), 354,284,256,236$; TLC (Merck $60 \mathrm{~F}_{254}, 0.25 \mathrm{~min}$ thickness) $R f=0.31$ (hexaneethyl acetate, $3: 1)$; $\mathrm{CD} \lambda(\mathrm{EtOH}) \mathrm{nm}(\Delta \varepsilon): 283(-2.1)$, $255(+4.2), 232(+18.8)$. Data for the ${ }^{13} \mathrm{C}-\mathrm{NMR}$ spectrum are shown in Table $\mathbf{I}$.

Prunusol $B(2) .[\alpha]_{\mathrm{D}}^{25}+10\left(c=0.2, \mathrm{CHCl}_{3}\right)$; UV $\lambda_{\max }$ $(\mathrm{EtOH}): 283 \mathrm{~nm}(\varepsilon=5700)$; IR $v_{\max }\left(\mathrm{CHCl}_{3}\right) \mathrm{cm}^{-1}: 3600$, $3300,2900,1750,1620,1510,1460,1380,1340,1200,1140$, $1100,960,830$ and $700 \mathrm{~cm}^{-1}$; ${ }^{1} \mathrm{H}-\mathrm{NMR} \delta(200 \mathrm{MHz}$, $\left.\mathrm{CDCl}_{3}\right): 1.20\left(3 \mathrm{H}, \mathrm{s}, 2-\mathrm{CH}_{3}\right), 1.70\left(2 \mathrm{H}, \mathrm{t}, \mathrm{H}_{3 \alpha}\right.$ and $\left.\mathrm{H}_{3 \beta}\right)$, $2.15\left(3 \mathrm{H}, \mathrm{s}, 8-\mathrm{CH}_{3}\right), 2.25\left(3 \mathrm{H}, \mathrm{s}, 7-\mathrm{CH}_{3}\right), 2.97(2 \mathrm{H}, \mathrm{d}$, $J=11 \mathrm{~Hz}, \mathrm{H}_{11 \alpha}$ and $\left.\mathrm{H}_{11 \beta}\right), 4.25\left(1 \mathrm{H}, \mathrm{t}, J=11 \mathrm{~Hz}, \mathrm{H}_{12}\right)$, $5.65\left(1 \mathrm{H}\right.$, br.s, $\left.4^{\prime \prime}-\mathrm{OH}\right), 6.66\left(2 \mathrm{H}, \mathrm{d}, J=7.5 \mathrm{~Hz}, \mathrm{H}_{3^{\prime \prime}}\right.$ and $\left.\mathrm{H}_{5^{\prime \prime}}\right), 6.87\left(2 \mathrm{H}, \mathrm{d}, J=7.5 \mathrm{~Hz}, \mathrm{H}_{2^{\prime \prime}}\right.$ and $\left.\mathrm{H}_{6^{\prime \prime}}\right)$; EI-MS $m / z$ : $562\left(\mathrm{M}^{+}\right), 354,284,256,236$; TLC (Merck $60 \mathrm{~F}_{254}, 0.25 \mathrm{~mm}$ thickness) $R f=0.28$ (hexane ethyl acetate, $3: 1$ ); CD $\lambda$ $($ EtOH) $\mathrm{nm}(\Delta \varepsilon): 283(+1.2), 255(-2.4), 232(-10.9)$. Data for the ${ }^{13} \mathrm{C}$-NMR spectrum are shown in Table I.

Acetylation of 1. A mixture of 1 (1.2 mg), acetic anhydride $(0.2 \mathrm{ml})$ and anhydrous pyridine $(0.2 \mathrm{ml})$ was kept at room temperature for $24 \mathrm{hr}$. The excess acetic anhydride was decomposed with methanol, and the solvent was removed under reduced pressure. The acetylated 1 was purified by preparative HPLC [Develosil SI-60-5 ( $8 \phi \times$ $250 \mathrm{~mm}$ ); hexane-EtOAc $(85: 15)]$ to give $1.0 \mathrm{mg}$ of an oily compound. Monoacetate of 1: ${ }^{1} \mathrm{H}-\mathrm{NMR} \delta(200 \mathrm{MHz}$, $\left.\mathrm{CDCl}_{3}\right): 2.15(3 \mathrm{H}, \mathrm{s}), 2.25(6 \mathrm{H}, \mathrm{s}), 2.97(2 \mathrm{H}, \mathrm{d}, J=11 \mathrm{~Hz})$, $4.25(1 \mathrm{H}, \mathrm{t}, J=11 \mathrm{~Hz}), 6.90(2 \mathrm{H}, \mathrm{d}, J=7.5 \mathrm{~Hz})$ and 6.95 $(2 \mathrm{H}, \mathrm{d}, J=7.5 \mathrm{~Hz})$; EI-MS: $m / z 604\left(\mathrm{M}^{+}\right)$.

Syntheses of 1 and 2. A mixture of $0.24 \mathrm{mmol}$ of $\gamma$-tocopherol $(100 \mathrm{mg}), 0.33 \mathrm{mmol}$ of $p$-coumaric acid $(60 \mathrm{mg})$ and $0.12 \mathrm{mmol}$ of $p$-toluenesulfonic acid $(20 \mathrm{mg})$ in dry dioxane was heated for $3 \mathrm{hr}$ in a boiling water bath. ${ }^{9}$ ) The reaction products, after removing the solvent by evaporation, were purified by preparative TLC and HPLC to afford $6.6 \mathrm{mg}$ and $6.9 \mathrm{mg}$ of two products (about $10 \%$ yield each). The spectral data and chromatographic behavior of each of synthetic compounds were identical with those of $\mathbf{1}$ and $\mathbf{2}$.

\section{Antioxidative assays}

(1) Thiocyanate method. Each sample $(16 \mu \mathrm{mol})$ was added to a mixed solution $(25 \mathrm{ml})$ of linoleic acid $/ 99.0 \%$ ethanol/0.2 $\mathrm{M}$ phosphate buffer. The mixed solution in a conical flask was incubated at $40^{\circ} \mathrm{C}$, and the peroxide value was determined by reading the absorbance at $500 \mathrm{~nm}$ after a coloring reaction with $\mathrm{FeCl}_{2}$ and thiocyanate. ${ }^{8)}$

(2) Thiobarbituric acid (TBA) method. A mixed solution was prepared and incubated as just described. The formation of malonaldehyde was measured by reading the absorbance at $532 \mathrm{~nm}$ after a reaction with thiobarbituric acid. ${ }^{10}$ 


\section{Results and Discussion}

The molecular formula of $\mathbf{1}$ was confirmed by the high-resolution mass spectrum to give a molecular ion peak at $m / z 562.4053$ (562.4022; calcd. for $\mathrm{C}_{37} \mathrm{H}_{54} \mathrm{O}_{4}$ ). In the ${ }^{1} \mathrm{H}-\mathrm{NMR}$ spectrum of 1 , two doublets $[\delta 6.66(2 \mathrm{H}$, $J=7.5 \mathrm{~Hz})$ and $\delta 6.87(2 \mathrm{H}, J=7.5 \mathrm{~Hz})]$ in the aromatic region suggested the presence of 1,4-disubstituted benzene ring $\left(\mathrm{H}_{2^{\prime \prime}}, \mathrm{H}_{3^{\prime \prime}}, \mathrm{H}_{5^{\prime \prime}}\right.$ and $\mathrm{H}_{6^{\prime \prime}}$ ). Moreover, $\mathrm{ABX}$-type signals at $\delta$ $2.94\left(\mathrm{H}_{11 \alpha}, \mathrm{dd}, J=16.3,2.5 \mathrm{~Hz}\right), \delta 2.99\left(\mathrm{H}_{11 \beta}\right.$, $\mathrm{dd}, J=16.3,6.3 \mathrm{~Hz})$ and $\delta 4.25\left(\mathrm{H}_{12}, \mathrm{dd}\right.$, $J=6.3,2.5 \mathrm{~Hz}$ ) were observed, and the coupling of these protons was confirmed by ${ }^{1} \mathrm{H}^{-1} \mathrm{H}$ COSY NMR spectrum. Two methylene protons at $\delta 1.62$ and $\delta 1.79\left(\mathrm{H}_{3 \alpha}\right.$, ddd, $J=16.3$, $7.5,6.9$ and $\mathrm{H}_{3 \beta}$, ddd, $\left.J=16.3,7.5,6.9\right)$ were coupled with the adjacent methylene protons at $\delta 2.29$ and $\delta 2.64\left(\mathrm{H}_{4 \alpha}\right.$, ddd, $J=16.9,7.5$, 6.9 , and $\mathrm{H}_{4 \beta}$, ddd, $\left.J=16.9,7.5,6.9\right)$. As shown in the ${ }^{13} \mathrm{C}-\mathrm{NMR}$ spectrum of 1 (Table I), it was strongly suggested that 1 contained an $\gamma$-tocopherol moiety as the partial structure of 1. All signals due to chroman ring and side chain of $\gamma$-tocopherol were observed: however, the 5-carbon in the chroman ring of 1 was observed at $\delta 115.3$ as a singlet, although the 5 -carbon of $\gamma$-tocopherol at $\delta 112.1$ was a doublet under the off-resonance condition. This data suggested that the 5-position of the chroman ring was substituted in $\mathbf{1}$. The methine proton $\left(\mathrm{H}_{12}\right)$ at $\delta 4.25$ was found to be attached to the carbon $(\mathrm{C}-12)$ at $\delta 36.9$ by the ${ }^{13} \mathrm{C}-{ }^{1} \mathrm{H}$ selective decoupling technique. Similarly, the methylene protons at $\delta 2.94\left(\mathrm{H}_{11 \alpha}\right)$ and $\delta 2.99$ $\left(\mathrm{H}_{11 \beta}\right)$ were observed to be attached to the carbon at $\delta 37.9$ (C-11). A $\mathrm{C}=\mathrm{O}$ absorption at $1750 \mathrm{~cm}^{-1}$ in the IR spectrum and a carbonyl carbon at $\delta 168.5$ in the ${ }^{13} \mathrm{C}-\mathrm{NMR}$ spectrum of 1 suggested the presence of a $\delta$-lactone ring.

Acetylation of 1 gave a monoacetate, and it was indicated that only the aromatic protons $\left(\mathrm{H}_{2 \prime \prime}, \mathrm{H}_{3^{\prime \prime}}, \mathrm{H}_{5^{\prime \prime}}\right.$ and $\mathrm{H}_{6^{\prime \prime}}$ in 1$)$ were shifted downfield by acetylation; therefore, a hydroxy group was assumed to be in the p-position of the benzene ring. From these results, it was assumed that prunusol $\mathrm{A}$ had one of two possible chemical structures, A or B as shown in Fig. 1. In the NOE difference spectrum of 1, a reasonable increase was observed at $\mathrm{H}_{12}$

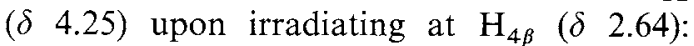

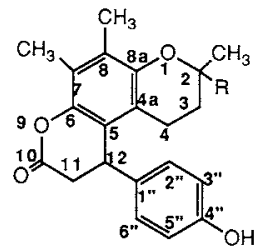

(A)<smiles>[H][R]1(C)CCc2c(c(C)c(C)c3c2CC(c2ccc(O)cc2)C(=O)O3)C1</smiles>

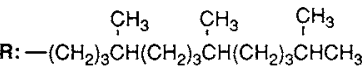

Fig. 1. Two Possible Structures for 1.

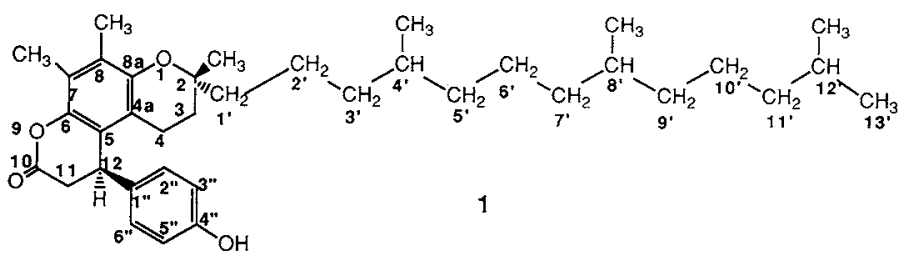<smiles>Cc1c(C)c2c(c3c1O[C@](C)(CCCC(C)CCCC(C)CCCC(C)C)CC3)[C@H](c1ccc(O)cc1)CC(=O)O2</smiles>

Fig. 2. Structures of $\mathbf{1}$ and $\mathbf{2 .}$ 
therefore, it is assumed that structure $\mathrm{A}$ is the preferred structure of 1 . By comparing the spectroscopic data of prunusol B with those of prunusol A, it was strongly suggested that prunusol B was the diastereoisomer of prunusol $A$, because of the difference in the values of their $[\alpha]_{\mathrm{D}}^{25}$ and CD spectra.

In order to confirm the structure of these prunusols, chemical syntheses of $\mathbf{1}$ and $\mathbf{2}$ were carried out by the coupling reaction of
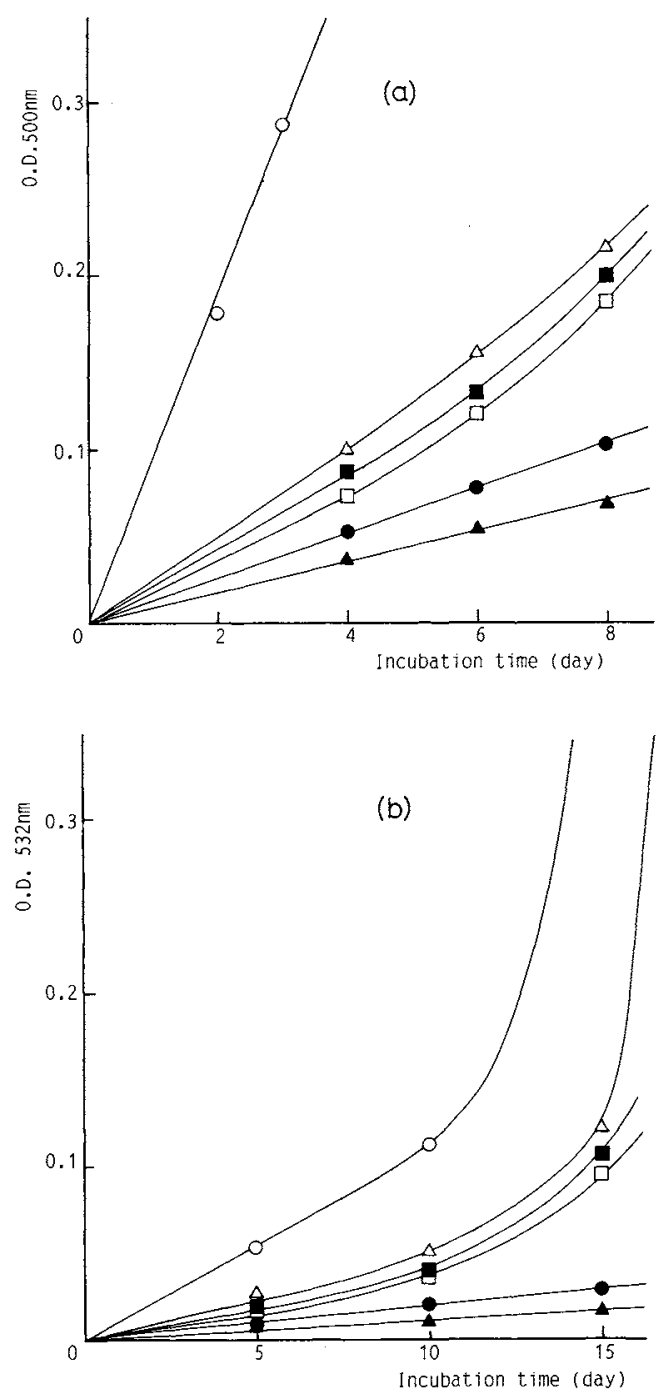

Fig. 3. Antioxidative activity of $\mathbf{1}$ and $\mathbf{2}$.

(a) Determined by the thiocyanate method.

(b) Determined by the thiobarbituric acid (TBA) method. $-\mathrm{O}$, control; - - - BHA; $-\triangle-, \alpha$-tocopherol; $-\mathbf{\Lambda}, \gamma$-tocopherol; $-\square-, 1 ;-\square-, 2$. $\gamma$-tocopherol with $p$-coumaric acid in the presence of $p$-toluenesulfonic acid, although the yield was only $10 \%$. Both 1 and 2 had the same absolute configuration $(R)$ as $\mathrm{D}-\gamma$ tocopherol at the 2-positions; ${ }^{11}$ therefore, the additional chiral center in $\mathbf{1}$ and $\mathbf{2}$ was assumed to exist at $\beta$-carbon of the $\delta$-lactone ring. Recently, Nonaka et al. have confirmed the stereochemical structures of cinchonains, phenylpropanoid-substituted epicatechins. ${ }^{9}$ The absolute configuration of the $\beta$-carbons of prunusols A and B can be established as shown in 1 and $\mathbf{2}$ (Fig. 2), respectively, by comparing their CD spectra with those of cinchonains.

In the Prunus leaf wax, a large amount of $\gamma$-tocopherol (about $1 \mathrm{mg} / \mathrm{g}$ of leaf wax) has been detected, ${ }^{7)}$ and $p$-coumaric acid is also widely distributed in the plant leaves. ${ }^{12)}$ Therefore, it is probable that phenylpropanoidsubstituted tocopherols such as prunusols A and $\mathrm{B}$ are produced between $\gamma$-tocopherol and $p$-coumaric acid in the leaves.

The antioxidative activity of prunusols $\mathrm{A}$ and $B$ was examined by the thiocyanate and TBA methods as shown in Fig. 3. Both 1 and 2 showed almost the same antioxidative activity as $\alpha$-tocopherol, but they showed less antioxidative activity than $\gamma$-tocopherol.

Acknowledgments. We wish to thank Emeritus Professor M. Namiki for valuable discussions, Dr. T. Kondo for measuring $500 \mathrm{MHz}{ }^{1} \mathrm{H}$-NMR spectra, and Mr. S. Kitamura for measuring MS data.

\section{References}

1) R. G. Cutler, in "Free Radicals in Biology," Vol. VI, ed. by W. A. Pryor, Academic Press, New York, 1984, pp. $371-428$.

2) B. Frei, L. England and B. N. Ames, Proc. Natl. Acad. Sci. U.S.A., 86, 6377 (1989).

3) R. A. Larson, Phytochemistry, 27, 969 (1988).

4) T. Osawa, M. Namiki and S. Kawakishi, in "Antimutagenesis and Anticarcinogenesis Mechanisms II," ed. by Y. Kuroda, D. M. Shankel and M. D. Waters, Plenum, New York, 1990, pp. 139-153.

5) T. Osawa and M. Namiki, Agric. Biol. Chem., 45, 735 (1981).

6) T. Osawa and M. Namiki, J. Agric. Food Chem., 33, 5 (1985).

7) T. Osawa, S. Kumazawa, S. Kawakishi and M. 
Namiki, in "Medical, Biochemical and Chemical Aspects of Free Radicals," ed. by O. Hayaishi, E. Niki, M. Kondo and T. Yoshikawa, Elsevier, Amsterdam, 1989, pp. 583-586.

8) H. Mitsuda, K. Yasumoto and K. Iwami, Eiyo to Shokuryo, 19, 210 (1966).

9) G. Nonaka and I. Nishioka, Chem. Pharm. Bull., 30, 4268 (1982).
10) A. Ottolenghi, Arch. Biochem. Biophys., 79, 355 (1959).

11) L. J. Machlin, "Vitamin E-A Comprehensive Treatise," Marcel Dekker Inc., New York (1980).

12) K. B. G. Torssel, Natural Product Chemistry, "A Mechanistic and Biosynthetic Approach to Secondary Metabolism," John Wiley \& Sons Ltd., New York, 1983. 